\title{
Intranest mutualisms between the forest fire ant Solenopsis virulens (Fr. Smith) (Hymenoptera; Formicidae) and two families of Hemiptera (Membracidae, Monophlebidae) in Brazilian Atlantic Forest
} Thalles Platiny Lavinscky Pereira1 ${ }^{\circledR \odot}$, Freddy Bravo ${ }^{2 \oplus}$ \& Jacques Hubert Charles Delabie ${ }^{3 \oplus}$

1. Museum of the North, University of Alaska Fairbanks, Fairbanks, Alaska, USA. 2. Departamento de Ciências Biológicas (DCBIO), Laboratório de Sistemática de Insetos (LASIS) - Feira de Santana, BA, Brazil. 3. Departamento de Ciências Agrárias e Ambientais, Universidade Estadual de Santa Cruz, Ilhéus, BA, Brazil/Cocoa Research Center - CEPLAC - Ilhéus, Bahia, Brazil.

\section{EntomoBrasilis 14: e966 (2021)}

\section{Edited by:}

Alberto Moreira Silva-Neto

\section{Article History:}

Received: 31.viii.2021

Accepted: 01.x.2021

Published: 01.xi.2021

Corresponding author:

Thalles Platiny Lavinscky Pereira

७ thallesplp@gmail.com

Funding agencies:

\& Coordenação de Aperfeiçoamento de Pessoal de Nível Superior; Fundação de Amparo à Pesquisa do Estado da Bahia; University of Alaska Fairbanks

\begin{abstract}
Hemipterans and ants are frequently recorded in trophobiotic associations, generally mutualism. Nests of the fire ant Solenopsis virulens (Smith) found at the base of trees in the Atlantic Forest biome, Brazil, were investigated for their commensal fauna. The present study provides new information about the mutualism between the fire ant with hemipterans Membracidae and Monophlebidae found in their nests, this report is the first mention of this kind of relationships in South America. Such associations are very common between ants and treehoppers but have seldom been reported with the family Monophlebidae.
\end{abstract}

Keywords: Agroforests; Bahia; Endoiastinae; entomology; Scytodepsa tricarinata.
$\mathbb{N}$ umerous trophobiotic associations, generally mutualisms, have been reported between ants and hemipterans of the suborders Auchenorrhyncha and Sternorrhyncha (DELABIE 2001). This kind of relationships are very common between these two groups of organisms and a range of studies have been carried out to better understand their intimate relationships, including natural history (Blaimer 2010; HaWkesWood \& TAylor 2018; Marques et al. 2018), physiology (BLANCHARD et al. 2019), nutritional dependences (Detrain et al. 2010), as well as complex studies involving models of mutualistic interaction networks (FAGUNDEs et al. 2016; Fornoff et al. 2019).

Solenopsis virulens (Smith) (Figure 1A) (ANTWEB 2021) is a fire ant species with monomorphic workers (PITTs et al. 2018). This ant builds conspicuous earthen mounds at the base of trees and herbaceous plants, fallen tree trunks and below stones (Pereira et al. 2015). This species inhabits the entire Northeast of South America and is found in forests or agroforests from the base of the Andes in Southern Bolivia to the Atlantic Coast of Bahia, Brazil (Trager 1991). Until now, no study about mutualistic and other kinds of interactions between this ant and hemipterans is available, except the description a new species of Psychodidae found in colonies of S. virulens (PEREIRA et al. 2015). The present study provides new information and illustration about the protective behavior, and interaction between the ant $S$. virulens and hemipterans of the Membracidae and Monophlebidae families sampled in a remnant of the biome Atlantic Forest in Northeastern Brazil.
The hemipterans were collected from three nests of $S$. virulens in April to May 2013 in the Michelin Ecological Reserve (REM) - Ouro Verde (Figure 1B - collection trail), in both municipalities of Ituberá and Igrapiúna, state of Bahia, Brazil. This reserve incorporates discontinuous areas of

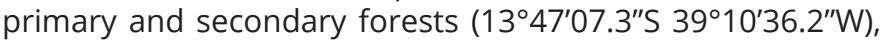
and the climate is considered wet equatorial (Köppen-Geiger climatic classification: Af). The Private Natural Heritage Reserve (RPPN) has an average annual rainfall close to 2,000 $\mathrm{mm}$ and temperatures that vary between $18^{\circ}$ and $30^{\circ} \mathrm{C}$, with rainfall distributed throughout the year (ICMBı 2021).

The hemipteran specimens found interacting with S. virulens were actively collected with forceps, and are deposited in the Prof. Johann Becker Entomology Collection at the Zoological Museum of the Universidade Estadual de Feira de Santana, Bahia, Brazil (MZFS). The biological material was identified based on external morphology to species or family levels by specialists (Dr. Ana Lúcia B. G. Peronti, Universidade Estadual Paulista; Dr. Penelope Gullan, The Australian National University; and Dr. Olivia Evangelista, Australian National Collection).

Individuals of two families of Hemiptera were found in three fire ant colonies. One nest sheltered 18 imagos and nymphs of Scytodepsa tricarinata Funkhouser (Auchenorrhyncha, Membracidae, Endoiastinae) (Figure 1C, 2B - white circle), and the other two nests sheltered around 100 individuals of a single morphospecies of the Monophlebidae family 
(Sternorrhyncha, Margarodidae sensu lato - probably a new genus and species) (Figure 1D, 2D, 3A-D). Species from these two families of hemipterans have already been reported living in mutualism with other ants, producing honeydew or wax and proteins in exchange for protection from predators. Such associations are very commonly reported for Membracidae (DELABIE 2001) but have seldom been recorded with the family Monophlebidae (as genus Icerya Signoret, in DeLABIE 2001).

The investigated $S$. virulens nests were found as conspicuous ground mounds in a remnant of native forest. The trees where the nests were found were close to a hiking trail which crosses the reserve. Two nests (10-20 cm in height) were leaning at the base of trunks. One nest had aboveground shelters reaching approximately one meter above the soil level (Figure 2C, selected area). The hemipterans were collected feeding directly on the trunk, inside the ant nest, near the tree basis. Most specimens were in contact with roots.

Although the passive and active defense behavior of ants to hemipterans in mutualisms is very common, we report and illustrate such a relationship for $S$. virulens for the first time. Their passive defense behavior involved building a structure from a layer of soil to hide/defend the hemipterans from potential predators or parasitoids, such as a protection shelter as does a range of other ants, in general, arboreal species. Figures 2A-B (A - before and B - after soil removed) and figures $2 C-D$ (C -before and $D$ - after soil removed) show the contrasting soil volume used by the ants to cover the hemipterans.

The active protection behavior observed between S. virulens and their hemipterans was no different from what has already been reported in the literature (STADLER \& DIXON 2008). The ants defended themselves against the forceps in all colonies and actively tried to protect individuals of both families of Hemiptera with stings and bites. Also, the ants inspected the hemipterans with their antennae and mandibles (Figure $3 A-D)$. It is well known that the presence of ants effectively reduces the populations of Hemiptera natural enemies (Hölldobler \& Wilson 1990; Delabie 2001; Stadler \& Dixon 2008), e.g., Hymenoptera endoparasitoids of Phenacoccus solenopsis Tinsley, the cotton mealybug (Xu et al. 2020).

The shrub from the genus Piper (Piperaceae) hosted the mutualism between $S$. tricarinata $\times$ S. virulens. This is the first record of membracids of the genus Scytodepsa associated with ants. Scytodepsa belongs to the subfamily Endoiastinae, which shows parental care behavior (DIETRICH et al. 2017) and have now been reported being assisted by ants, characteristics that are common in other membracids with reported close relationships with ants. Although aboveground carton shelters have frequently been described ("cowsheds" in ANDERSON \& McShea 2000 - review) for arboreal ants (eg., Crematogaster, MckameY 1992), they are seldom described for ground mounds and membracids (KLIMEs et al. 2018), and this report is then the first mention of this kind of relationships

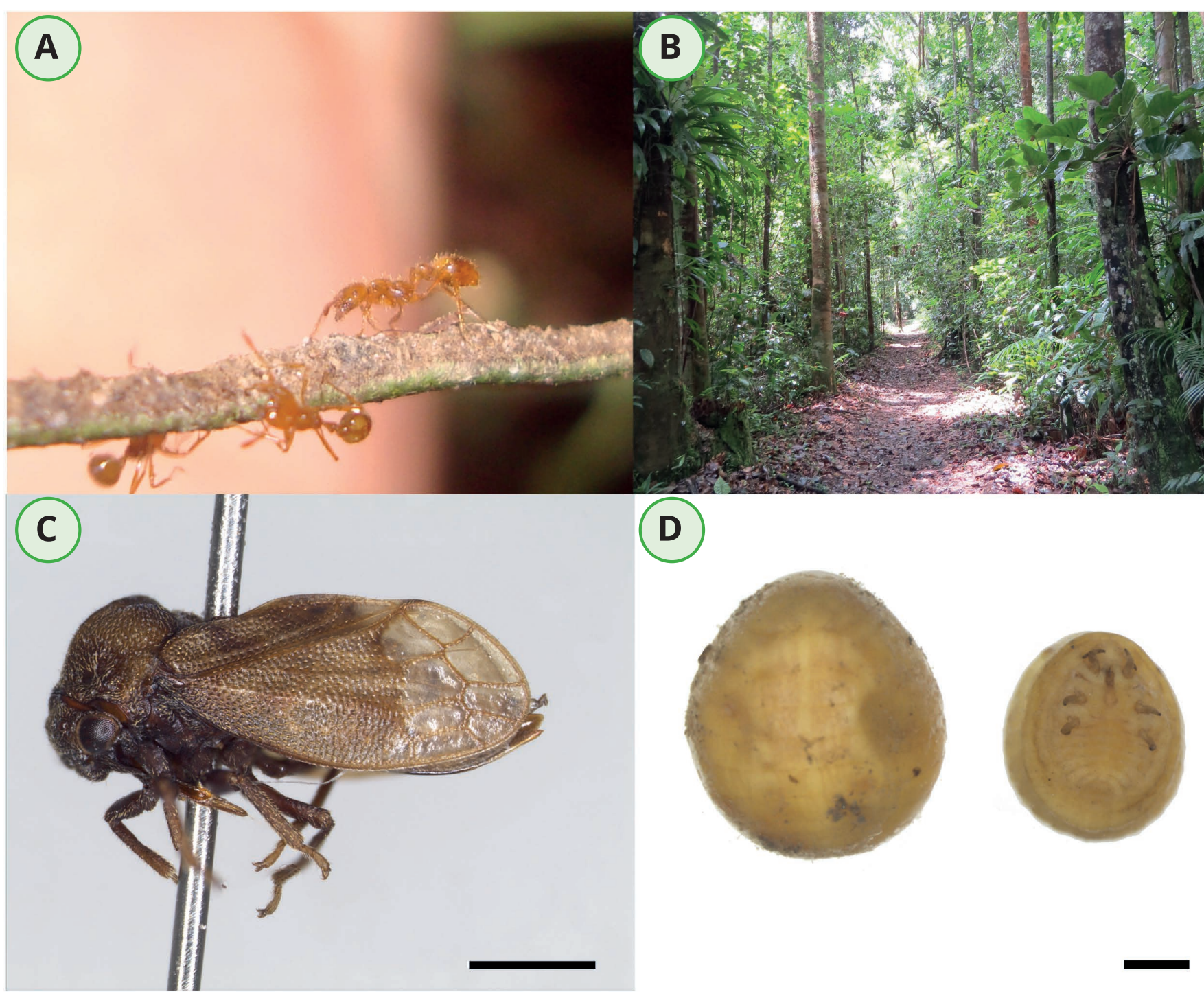

Figure 1. A. Solenopsis virulens (Smith) (Hymenoptera: Formicidae: Myrmicinae); B. Collection trail - Michelin Ecological Reserve (REM) - Ouro Verde RPPN - Bahia - Brazil - C. Scytodepsa tricarinata Funkhouser (Hemiptera: Auchenorrhyncha: Membracidae); D. Unidentified Monophlebidae (Hemiptera: Sternorrhyncha), dorsal (left) and ventral (right) view. Scale bars: C-D = 1mm. 


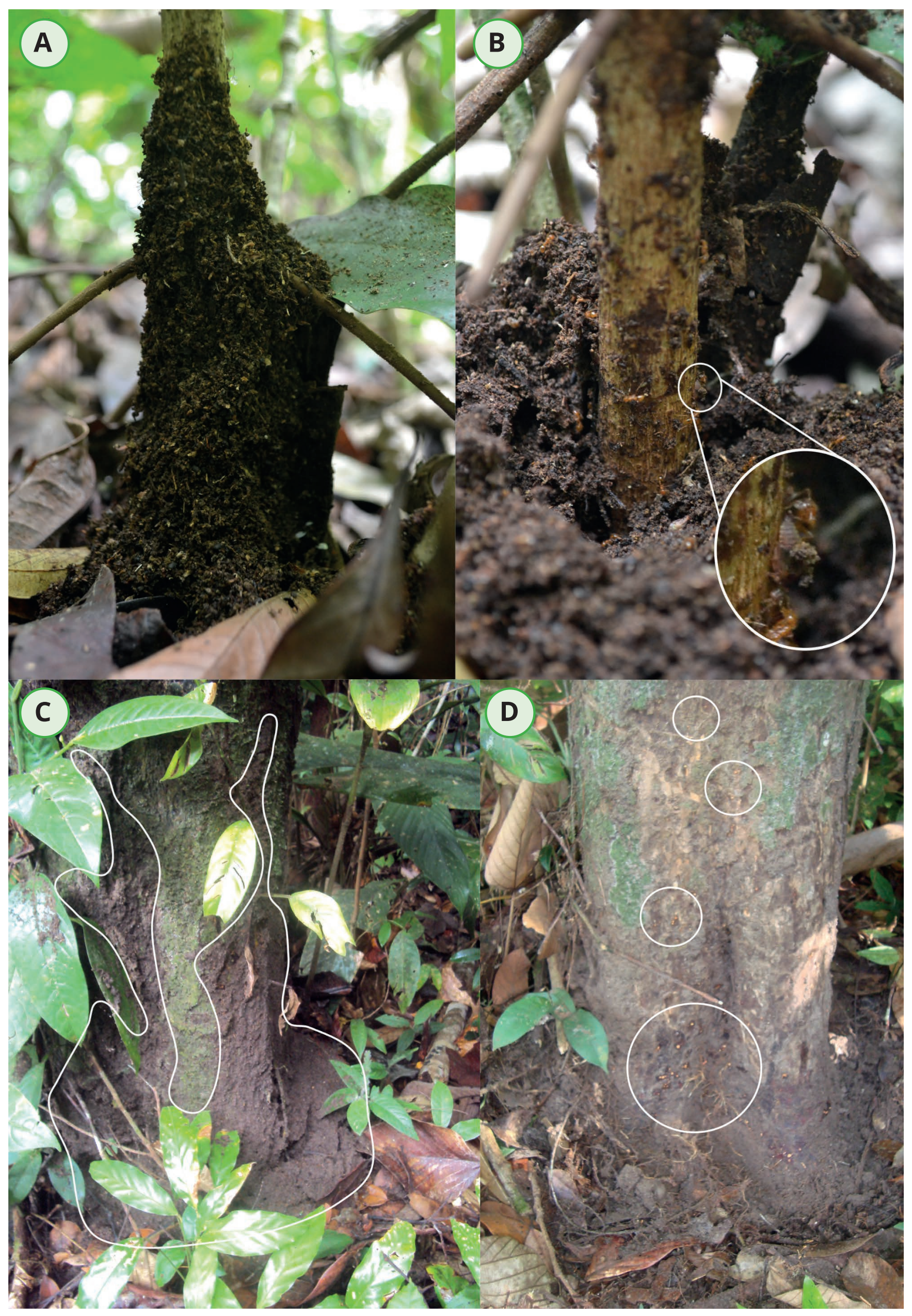

Figure 2. Solenopsis virulens (Smith) (Hymenoptera: Formicidae: Myrmicinae) nests. A.B. Nest on Piper (Piperaceae) shrub. A. Before soil removal B. After soil removal, white circles = Scytodepsa tricarinata Funkhouser (Hemiptera: Auchenorrhyncha: Membracidae) nymph detail. C.D. Nest on tree C. Before soil removal, selected area = nest. D. After soil removal, white circle = unidentified Monophlebidae in detail. 


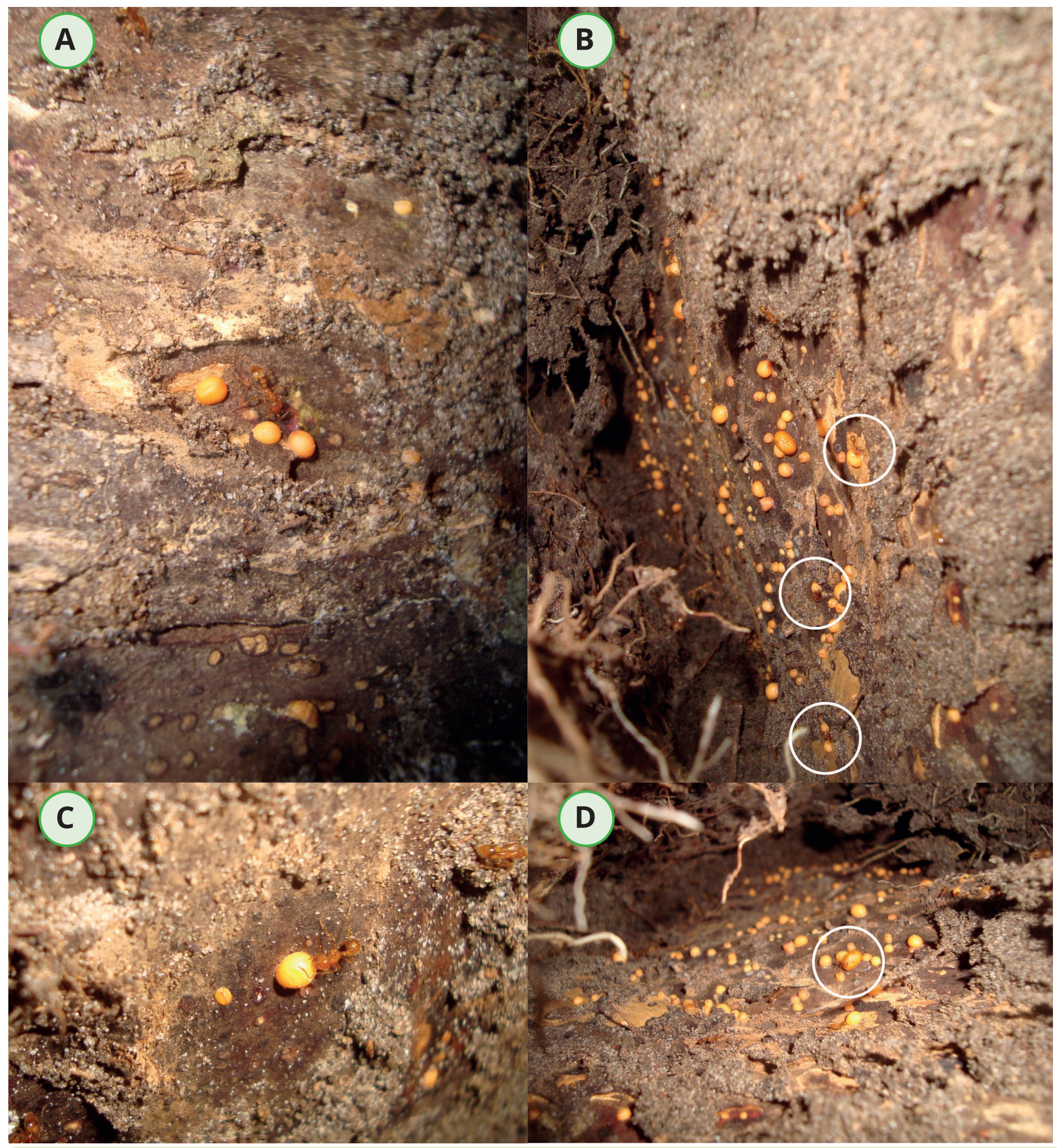

Figure 3. Interaction between Solenopsis virulens (Smith) (Hymenoptera: Formicidae: Myrmicinae) and unidentified Monophlebidae (Hemiptera: Sternorrhyncha). A.B.C.D. S. virulens interacting with the Monophlebidae sp. White circles = interaction in detail.

in South America.

The interaction between the family Monophlebidae (Margarodidae sensu lato) and the fire ant S. virulens is being reported herein for the first time. Reports of Monophlebidae interacting with ants (MARICONI \& ZAMITh 1960; HAWKESWOOD \& TAYLOR 2018) and protected by an ant-constructed shelter have already been mentioned but were not illustrated nor detailed, such as in Mimosicerya schraderae (Vayssière) in Panama (VAYssière \& Hughes-SCHRADER 1948 - unidentified ant).

Other studies described fire ants sheltering mealybugs (Pseudococcidae) (HELMS \& VINSON 2002) and plant nectaries (Ávila-NúÑEz \& Otero 2018). Behavioral similarities between other fire ants were pointed out by HeLMS \& VINSOn (2002): Solenopsis invicta Buren builds shelters in the ground housing the mealybug Antonina graminis (Maskell) and aboveground shelter maintains aphid colonies (Hemiptera: Aphididae).

It is important to highlight that Monophlebidae, Margarodidae sensu stricto and Margarodidae sensu lato had suffered taxonomic important changes in the past few decades (Foldi 2005; Ben-Dov 2011; Foldi \& Gullan 2014), and former information about the mutualisms between Margarodidae/Monoplebidae and ants needs to be checked.

The discovery of a putative new genus of Monoplebidae in the Atlantic Forest only reinforces the need to know more about the fauna diversity and preserve the Biome. Finally, understanding more about the mutualisms between ants and hemipterans could help reaffirm evolutionary hypotesis about these two groups of organisms (eg. when 
this interaction first occurred in the phylogeny of the groups (DIETRICH et al. 2017)), and the results found herein fill an information gap about the biology of these insects.

\section{ACKNOWLEDGMENTS}

The authors are in debt with Dr Olivia Evangelista (Australian National Collection) for Membracidae identification, and Dr. Ana Lúcia B.G. Peronti (Universidade Estadual Paulista), Dr. Imre Foldi (Museum National d'Histoire Naturelle) and Dr. Penelope Gullan (The Australian National University) for identifying the Monoplebidae; Marcos Aragão and Maira Xavier for their support with the pictures and with field work. Thanks to Hannah Doerrier (HDTranslationsbr) and Taylor Kane for the English revision. The authors acknowledge the Michelin Ecological Reserve (REM) which supported this study. TPLP thanks to the Centennial Postdoctoral Initiative (University of Alaska Fairbanks) for the Post Doctoral Fellow. Thanks to Coordination for the Training of Higher Education Personal (CAPES) for the Master's fellowship of TPLP Finance Code 001; to SECTI/FAPESB-CNPq PRONEX program PNX0011/2009. JHCD acknowledges his research grant from CNPq. The authors thanks to Marcelo Santis and Eduarda Viegas for the valuable comments and suggestions.

\section{REFERENCES}

Anderson, C, \& DW McShea, 2001. Intermediate-level parts in insect societies: adaptive structures that ants build away from the nest. Insectes Sociaux, 48: 291-301. DOI: https://doi.org/10.1007/PL00001781

AntWeb. Version 8.64.2. California Academy of Science. Avaliable on: <https://www.antweb.org/description.do ?genus=solenopsis\&species=virulens\&rank=species $>$ [Access: 30.ix.2021].

Ávila-Núñez, JL \& LD Otero, 2018. Structures built by Solenopsis geminata (Fabricius, 1804) near fern nectaries. Entomotropica, 35: 15-20.

Ben-Dov, Y, 2011. An updated checklist of the scale insects (Hemiptera: Coccoidea) of the Margarodidae sensu lato group. Zootaxa, 2859: 1-62. DOI: https://doi.org/10.11646/ zootaxa.2859.1.1.

Blaimer, BB, 2010. Taxonomy and natural history of the Crematogaster (Decacrema)-group (Hymenoptera: Formicidae) in Madagascar. Zootaxa, 2714: 1-39. DOI: https://doi.org/10.11646/zootaxa.2714.1.1

Blanchard, S, G Lognay, F Verheggen \& C Detrain, 2019. Today and tomorrow: Impact of climate change on aphid biology and potential consequences on their mutualism with ants. Physiological Entomology, 44: 77-86. DOI: https://doi.org/10.1111/phen.12275

Delabie, JH, 2001. Trophobiosis between Formicidae and Hemiptera (Sternorrhyncha and Auchenorrhyncha): an overview. Neotropical Entomology, 30: 501-516. DOI: https://doi.org/10.11646/zootaxa.2714.1.1

Detrain, C, FJ Verheggen, L Diez, B Wathelet \& E Haubruge, 2010. Aphid-ant mutualism: how honeydew sugars influence the behaviour of ant scouts. Physiological Entomology, 35: 168-174. DOI: https://doi.org/10.1111/ j.1365-3032.2010.00730.x

Dietrich, $\mathrm{CH}$, JM Allen, AR Lemmon, EM Lemmon, DM Takiya, O Evangelista, KKO Walden, PGS Grady, KP Johnson \& B Wiegmann, 2017. Anchored Hybrid EnrichmentBased Phylogenomics of Leafhoppers and Treehoppers (Hemiptera: Cicadomorpha: Membracoidea). Insect Systematics and Diversity, 1: 57-72. DOI: https://doi.org/10.1093/isd/ixx003

Fagundes, R, W Dáttilo, SP Ribeiro, V Rico-Gray \& K Del-Claro, 2016. Food source availability and interspecific dominance as structural mechanisms of ant-plant-hemipteran multitrophic networks. Arthropod-Plant Interactions, 10: 207-220. DOI: https://doi.org/10.1007/s11829-016-9428-x
Foldi, I, \& PJ Gullan, 2014. Review of the Neotropical scale insects formerly assigned to Coelostomidiidae and here transferred to a new tribe within the Monophlebidae (Hemiptera: Sternorrhyncha: Coccoidea). Zootaxa, 3903: 1-62. DOI: https://doi.org/10.11646/zootaxa.3903.1.1

Foldi, I, 2005. Ground pearls: a generic revision of the Margarodidae sensu stricto (Hemiptera: Sternorrhyncha: Coccoidea), pp. 81-125. In: Annales de la Société entomologique de France. Taylor \& Francis Group.

Fornoff, F, AM Klein, N Blüthgen \& M Staab, 2019. Tree diversity increases robustness of multi-trophic interactions. Proceedings of the Royal Society B, 286: 20182399. DOI: https://doi.org/10.1098/rspb.2018.2399

Hawkeswood, T] \& S Taylor, 2018. Red Meat Ants, Iridomyrmex purpureus (Smith, 1858)(Hymenoptera: Formicidae) feeding from an adult of the Giant Scale Bug, Icerya acaciae (Morrison \& Morrison, 1923) (Hemiptera: Monophlebidae). Calodema, 680: 1-4. https://doi.org/10.1007/s11829-0169428-x

Helms, KR \& SB Vinson, 2002. Widespread association of the invasive ant Solenopsis invicta with an invasive mealybug. Ecology, 83(9): 2425-2438. DOI: https://doi. org/10.1890/0012-9658(2002)083[2425:WAOTIA]2.0.CO;2

Hölldobler, B \& EO Wilson, 1990. The ants. The Belknap Press of Harvard University Press, Cambridge, Massachusets, USA.

ICMBio - Instituto Chico Mendes de Conservação da Biodiversidade. Avaliable on: <http://www.icmbio.gov.br/ portal/images/stories/DCOM_plano_de_manejo_RPPN_ Ouro_Verde.pdf> [Access: 24.iii.2021]

Klimes, P, M Borovanska, NS Plowman \& M Leponce, 2018. How common is trophobiosis with hoppers (Hemiptera: Auchenorrhyncha) inside ant nests (Hymenoptera: Formicidae)? Novel interactions from New Guinea and a worldwide overview. Myrmecol. News, 26: 31-45. DOI: https://doi.org/10.25849/myrmecol.news_026:031

Mariconi, FA, \& AP Zamith, 1960. Contribuição para o conhecimento da Mimosicerya hempeli (Cockerell, 1899) (Homoptera. Margarodidae) e de seu predador Exoplectra erythrogasfer Mulsant, 1851 (Coleoptera, Coccinellidae). Anais da Escola Superior de Agricultura Luiz de Queiroz, 17: 223-238. DOI: https://doi.org/10.1590/S007112761960000100020

Marques, TE, EB de Azevedo Koch, IS dos Santos, JRM dos Santos, CDSF Mariano, S. F., \& JH Delabie, 2018. The diversity of ants (Hymenoptera: Formicidae) interacting with the invasive hibiscus mealybug Maconellicoccus hirsutus (Green 1908) (Hemiptera: Pseudococcidae) on ornamental and cultivated plants in Bahia, Brazil. Arthropod-plant interactions, 12: 237-246. https://doi.org/10.1007/s11829-017-9563-z

Mckamey, SH, 1992. Reappraisal of the Neotropical treehopper genus Eunusa Fonseca (Homoptera: Membracidae), with ecological notes. Annals of the Entomological Society of America, 85: 253-257. DOI: https://doi.org/10.1093/ aesa/85.3.253

Pereira, TPL, F Bravo, MX Araújo, D Cordeiro, C Chagas \& JHC Delabie, 2015. Moth flies (Diptera: Psychodidae) collected in colonies of the fire ant Solenopsis virulens (Smith) (Hymenoptera: Formicidae), with description of two new species. Sociobiology, 62: 18-22. DOI: https://doi.org/10.13102/sociobiology.v62i1.18-22

Pitts, JP, GP Camacho, D Gotzek, JV Mchugh \& KG Ross, 2018. Revision of the fire ants of the Solenopsis saevissima species-group (Hymenoptera: Formicidae). Proceedings of the Entomological Society of Washington, 120: 308-411. DOI: https://doi.org/10.4289/0013-8797.120.2.308

Stadler, B \& AFG Dixon, 2008. Mutualism: ants and their insect partners. Cambridge University press, Cambridge.

Trager, JC, 1991. A revision of the fire ants, Solenopsis geminata group (Hymenoptera: Formicidae: Myrmicinae). Journal of 
the New York Entomological Society, 141-198.

Vayssière, P \& S Hughes-Schrader, 1948. Étude morphologique et biologique Nautococcus schraderae Vayss. (CoccoideaMargarodidae). Mémoires du Museum National d'Histoire Naturelle, New Series, Série A (Zoologie), 26: 57-74.
Xu, C, Q Li, X Qu, J Chen \& A Zhou, 2020. Ant-hemipteran association decreases parasitism of Phenacoccus solenopsis by endoparasitoid Aenasius bambawalei. Ecological Entomology, 45: 290-299. DOI: https://doi.org/10.1111/ een. 12797

$\star * * * * * * * * *$

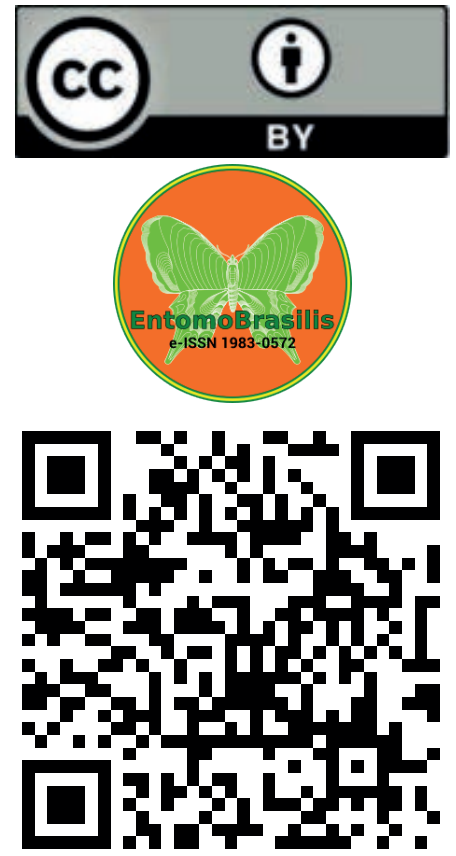

